\title{
Jeanette Little and the
}

Jeanette Little Scholarship by Cindy Vanuaroro

$\mathrm{J}$ eanette Little served in Fiji at the George Knight Theological Library of the Pacific Theological College for many years. At the same time, amongst other jobs, she also served as a consultant for theological libraries in the South Pacific.

I first met Jeanette in January 1991 during a month long library workshop based at the Pacific Regional Seminary in Suva, Fiji which she organized. At the time, I realised that most of the other participants knew Jeanette because she had helped them to take up University of the South Pacific courses on Librarianship through the South Pacific Association of Theological Schools (SPATS) scholarships. I believed she had helped them all the way through their courses.

After the 1991 workshop, I also became a recipient of a SPATS scholarship for Pacific Theological librarians to do studies in librarianship. This enabled me to get in touch with Jeanette more and more, especially to discuss issues arising from the library profession.

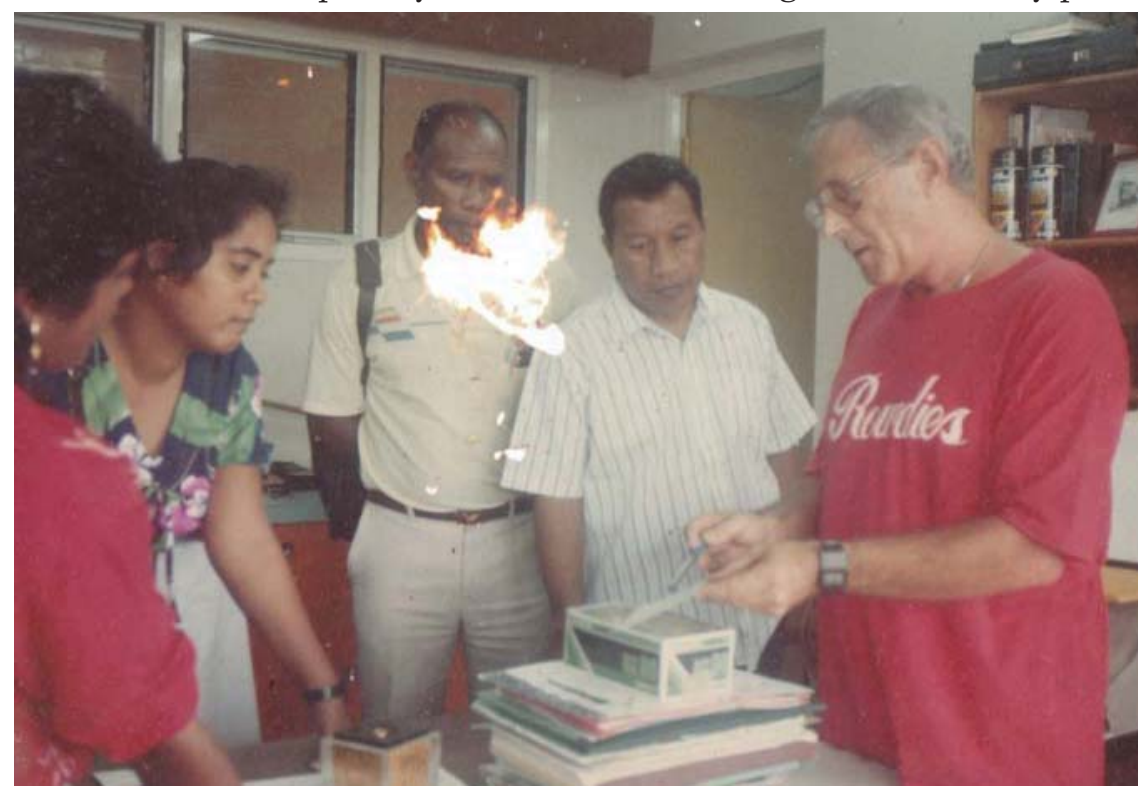

1991 Library Workshop, Suva, Fiji - participants at the Marist Centre Listening to the Librarian's talk on preserving historical records

In 2001, it was through Jeanette that some of us were able to attend the Australia and New Zealand Theological Library Association (ANZTLA) Conference in Auckland, New Zealand, and to have some basic library training at the St. John's Kinder Library 
after the conference. I vividly remember those moments with her. She had a gentle spirit, she was someone who cared, she listened with understanding, and was always willing to help whenever a need arose. She had a heart for the people of the Pacific, especially for the librarians and their libraries. It was unfortunate that she could not visit the Talua library as arranged, due to her illness and return to Australia.

Sadly, after a long illness, Jeanette left the fellowship of librarians in 2003 to be with her Lord. That year was when the Jeanette Little Scholarship was announced at the Perth ANZTLA Conference. I relate with deep emotion and acknowledgment that it was through her work that theological libraries of the South Pacific can be members of the ANZTLA today. A tribute to her was written by Judith Bright and Helen Greenwood on behalf of the ANZTLA Members (ANZTLA Newsletter, No.51, December, 2003, p. 22).

How are we Pacific theological librarians and libraries beneficiaries of the Scholarship Fund today?

Libraries like the Don Lewis Pacific Partnership Library (formerly Talua Library) are very fortunate to be recipients of this scholarship. Our library survives on such sources to maintain the high standard it has now. It provides for membership of ANZTLA and the ARI Index subscription. The scholarship can also help train personnel.

It was through her influence that we pacific librarians could continue to attend conferences (as above) that enhance our skills and knowledge as librarians.

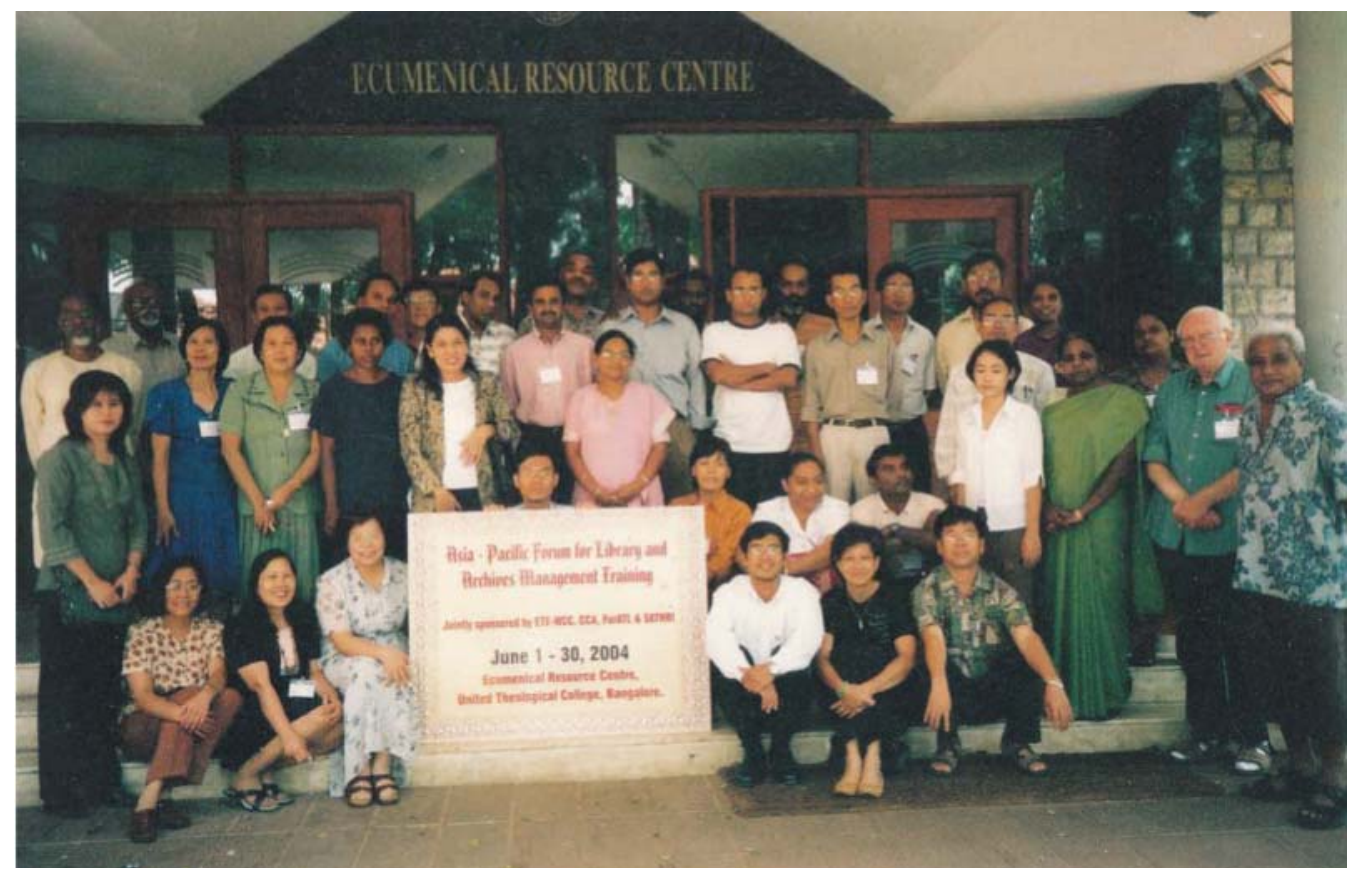

Bangalore Archive Course, 2004 
"One of the dreams of the library was to computerize the collection and the executive council had approved to have the Bookmark program but we were unable to because of the cost ... through the Australian Presbyterian World Mission (APWM), the program was purchased and will be installed soon."
I was privileged to attend the 2009 ANZTLA Conference in Canberra as a JLSS recipient and I will give another example of how the scholarship has benefited the Don Lewis Pacific Partnership Library.

One of the dreams of the library was to computerize the collection and the executive council had approved to have the Bookmark program but we were unable to because of the cost.

After the Conference at the Sundowner Resort, I moved on to Brisbane and spent a week there. I had some time in the library at Mount Gravatt Campus, Harvest Bible College where the "Bookmark" is in use. I was able to get some idea of how the program works. The second dimension of the Brisbane visit was to see Christian brothers and sisters who had been partners with Talua for so many years through different projects. I was able to share our need of this computer program. We prayed that someone would be interested in helping with the purchase of the program. God answered these prayers during a night of prayer with a group of ladies in Brisbane when they offered to make this a project of theirs. Therefore, through the Australian Presbyterian World Mission (APWM), the program was purchased and will be installed soon.

Pacific Theological Libraries who have not benefited, or may not be aware of the scholarship can go to the ANZTLA website http://www.anztla.org or email ANZTLA Secretary Wendy Davis atwendy.davis@flinders.edu.au

Rachel Conor's help in editing this article is acknowledged, March 2010 